\title{
Prototype Mesin Presensi Berbasis E-mail Pada SMP Assyairiyah Attahiriyah Jakarta
}

\author{
Sunandar ${ }^{1}$, Herlawati ${ }^{1,}$ \\ * Korespondensi: e-mail: herlawati@ubharajaya.ac.id
}

\begin{abstract}
1 Program Studi Informatika; Universitas Bhayangkara Jakarta Raya; Jl. Raya Perjuangan, Marga Mulya, Bekasi Utara, Jawa Barat 17121. Telp: 021- 88955882 , 889955883; e-mail: sunandarotomotif@gmail.com, herlawati@ubharajaya.ac.id
\end{abstract}

Submitted: 12 Oktober 2020

Revised: 2 November 2020

Accepted: 16 November 2020

Published: $\mathbf{3 0}$ November 2020

\begin{abstract}
This research discusses the design of E-mail-based Presence Machine Prototype in Assyairiyah Attahiriyah Junior High School Jakarta which aims to information for parents and schools who have difficulty monitoring student attendance at school, thus helping to manage student presence data more effectively and efficiently. The system development method used is the Prototype method. Data obtained by conducting interviews and direct observation of spaciousness to get right data as needed. The results of this research are hardware and software, in the process of making hardware using NodeMCU, LCD 16x2, Buzzer and Fingerprint Sensor and the software uses the PHP programming language with MySql database. The presence of the Presence Machine Prototype becomes a means for parents and schools to process and get information related to student attendance in schools effectively and efficiently.
\end{abstract}

Keywords: Presence Machine, Presence, Prototype, NodeMCU.

\section{Abstrak}

Penelitian ini membahas perancangan Prototype Mesin Presensi Berbasis E-mail yang bertujuan sebagai sarana informasi bagi orang tua maupun pihak sekolah yang kesulitan memonitoring kehadiran siswa disekolah, sehingga membantu pengelolaan data presensi siswa menjadi lebih efektif dan efisien. Metode pengembangan sistem yang digunakan adalah metode prototype. Data diperoleh dengan melakukan wawancara serta observasi langsung kelapangan guna mendapat data yang akurat sesuai yang dibutuhkan. Hasil penelitian ini berupa hardware dan software, dalam proses pembuatan hardware menggunakan NodeMCU, LCD 16x2, Buzzer dan Sensor Fingerprint serta softwarenya menggunakan bahasa pemrograman PHP dengan database MySql. Adanya Prototype Mesin Presensi ini menjadi sarana bagi orang tua dan sekolah untuk mengolah dan mendapatkan informasi terkait presensi siswa disekolah dengan efektif dan efisien.

Kata Kunci: Mesin Presensi, Presensi, Prototype, NodeMCU.

\section{Pendahuluan}

Sidik jari merupakan ciri khas yang dimiliki setiap orang dengan keunikan nya masingmasing ini berguna untuk membedakan identitas seseorang dengan orang lainnya. Ada teknologi yang dipakai saat ini untuk mengenali sidik jari seseorang yaitu teknologi biometric yang dapat mengenali sidikjari manusia melalui sensor sidik jari optikal. Dengan keunikan sidik jari seseorang menjadikannya sebuah identitas diri yang sangat baik. 
Penggunaan sidik jari ini bisa digunakan untuk meminimalisir kecurangan atau pemalsuan data siswa, yang secara tidak langsung akan meningkatkan tingkat presensi siswa disekolah dan meningkatkan kinerja pihak sekolah karena proses pencatatan presensi siswa menjadi lebih terdata dengan baik.

Proses pendataan kehadiran atau pendataan presensi merupakan kegiatan yang dilakukan dalam sebuah acara guna mengetahui jumlah seseorang yang hadir, data presensi menjadi salah satu tolak ukur dalam menentukan kualitas seorang siswa. Sebelum melakukan kegiatan belajar mengajar mereka melakukan kegiatan presensi ini berguna untuk mengetahui nama-nama siswa yang hadir dikelas maupun yang absen. Maka dari itu kegiatan presensi ini dilakukan murid (sekretaris) dengan mencatat keterangan kehadiran siswa pada buku absen serta melakukan rekap kehadian tiap bulannya. Beberapa sekolah masih melakukan presensi dengan metode tersebut yang kemudian direkap oleh guru piket tiap bulannya untuk mengetahui presensi maupun absensi siswanya.

Pada Oktober 2019 tercatat bahwa ada 51 siswa absen sekolah. Absennya siswa diakibatkan banyak faktor, diantaranya kecanduan main game dan nongkrong, mereka berangkat dari rumah namun tidak sampai disekolah. Saat ini tidak ada sistem yang dapat mengolah dan memonitoring kehadiran siswa disekolah, faktor kesibukan orang tua dan tidak adanya sarana monitoring siswa menyebabkan pengawasan orang tua terhadap anak berkurang ,sehingga orang tua tidak dapat memantau perkembangan anak disekolah. Orang tua hanya tahu jika anak berangkat sekolah artinya mereka sekolah, padahal tidak demikian. Tidak adanyanya sistem menyebabkan pula siswa merasa tidak takut untuk membolos sekolah dan merasa bersalah karena ia merasa perbuatannya tidak diketahui oleh orang tuanya,. Untuk itu diperlukan adanya sistem dengan memanfaatkan teknologi saat ini guna memberikan pelaporan serta pemantauan siswa yang dapat dilakukan dengan cepat dan efektif.

E-mail (Electronic Mail) atau surat elektronik adalah sarana kirim mengirim surat melalui jalur jaringan komputer, dengan surat biasa umumnya pengirim perlu membayar per pengiriman, tetapi surat elektronik umumnya biaya yang dikeluarkan adalah biaya untuk membayar sambungan internet, saat ini e-mail sangat cocok digunakan sebagai media pemberitahuan kehadiran / kepulangan siswa dari sekolah.

Berdasarkan latar belakang tersebut, dapat diidentifikasikan permasalahan yang ada yaitu: (1) Tingginya tingkat absensi siswa. (2) Tidak adanya sistem untuk mengelola data presensi siswa. (3) Sulitnya orang tua memonitoring presensi siswa karena orang tua hanya mendapat rekap kehadiran pada saat pembagian rapor saja. (4) Tidak adanya sistem yang memberikan informasi terkait kehadiran dan kepulangan siswa dari sekolah kepada orang tua. (5) Data seringkali rancu, karena ada perubahan data meneggunakan tipe-x, sehingga menimbulkan indikasi data dimanipulasi.

Beberapa penelitian terkait penelitian ini antara lain: Pertama, tentang sistem presensi menggunakan NodeMCU untuk mengontrol sistem presensi pegawai menjadi lebih efektif dan efisien (Aji et al., 2020). Kedua, tentang sistem kehadiran menggunakan arduino untuk 
memonitoring kehadiran siswa dengan notifikasi sms sebagai kerja sama antara orang tua dan sekolah (Habibullah et al., 2018), Ketiga, tentang merancang sistem infromasi absensi untuk membantu pihak sekolah dan siswa dalam proses absensi siswa (Kuswara \& Kusmana, 2017), serta penelitian lainnya yaitu (Andalia \& Setiawan, 2015; Andita et al., 2016; Efrianto \& Fahruzi, 2016; Faizal \& Putri, 2017; Hendini, 2016; Ismaredah, 2015; Kurnia \& Widiasih, 2019; ; Martono, 2020; Maulana et al., 2019; Wiryadinata et al., 2017; Wulanningrum \& Pamungkas, 2018).

Tujuan dari penelitian ini adalah: (1) Membuat dan merancang prototype mesin presensi yang digunakan sebagai sarana informasi dari sekolah untuk orang tua siswa. (2) Memberikan kemudahan pihak sekolah dalam mengolah data presensi siswa. (3) Memberikan informasi presensi siswa kepada orang tua melalui e-mail. Dengan pencapaian tujuan penelitian tersebut, manfaat penelitian ini adalah: (a) Menurunkan tingkat absensi siswa disekolah. (b) Mempermudah sekolah dalam memberikan informasi terkait presensi siswa disekolah. (c) Sebagai sarana dokumentasi presensi dan absensi siswa. (d) Dengan termonitoringnya kehadiran siswa maka akan meningkatkan kedisiplinan siswa terhadap presensinya disekolah, dengan begitu akan meningkatkan prestasi siswa disekolah.

Agar pengerjaan penelitian ini terarah, maka penelitian ini difokuskan pada pembahasan sebagai berikut: (1) Sistem informasi ini dibuat hanya untuk mengelola data presensi siswa disekolah. (2) Prototype mesin presensi berbasis E-mail dibuat untuk diimplementasikan di SMP Assyairiyah Attahiriyah. (3) Target pengguna prototype ini adalah siswa, orang tua dan walikelas.

\section{Metode Penelitian}

Metode yang digunakan dalam proses pengumpulan data, diantaranya: (a) Metode observasi, penulis melihat langsung alur dan mempelajari dokumen-dokumen yang digunakan untuk mengumpulkan data tersebut di SMP Assyairiyah Attahiriyah. (b) Metode wawancara, penulis melakukan tanya jawab langsung kepada pihak sekolah SMP Assyairiyah Attahiriyah terutama terhadap kepala sekolah dan bagian kesiswaan guna mengetahui permasalahan yang dihadapi dan mendiskusikan sistem yang harus dibuat untuk memecahkan permasalahan tersebut. (c). Metode Studi Pustaka, penulis mengambil data dari SMP Asyyairiyah untuk dijadikan bahan dalam berbagai bentuk, dan mengambil acuan dari berbagai jurnal yang berhubungan dengan pembuatan skripsi ini.

Metode pengembangan sistem yang digunakan adalah metode prototype dengan tahapan-tahapan: (1) Pengumpulan kebutuhan, Pelanggan dan pengembang bersama-sama mendefinisikan format seluruh perangkat lunak, mengidentifikasikan semua kebutuhan dan garis besar sistem yang akan dibuat. (2) Membangun prototyping, Membangun Prototyping dengan membuat perancangan sementara yang berfokus pada penyajian yang ditujukan pada pelanggan dibuat contoh input dan output. (3) Evaluasi prototyping, Evaluasi prototyping dilakukan oleh pelanggan apakah prototyping yang sudah dibangun sudah sesuai dengan 
keinginan pelanggan, jika sudah maka lanjut ke proses selanjutnya, jika tidak maka diulang ke langkah awal. (4) Mengkodekan system, Dalam tahap prototyping yang sudah disepakati kemudian diterjemahkan kedalam bahasa pemrograman yang sesuai. (5) Menguji system, Setelah sistem sudah menjadi suatu perangkat lunak yang siap pakai, maka di tes terlebih dahulu sebelum digunakan, pengujian ini dilakukan dengan black box, basis path dan pengujian arsitektur dan lain-lain. (6) Evaluasi system, Pelanggan mengevaluasi apakah sistem yang sudah jadi sesuai dengan yang diharap. Jika ya, maka proses akan dilanjutkan ke penggunaan perangkat, namun jika perangkat lunak tidak sesuai / belum sesuai maka tahapan sebelumnya akan diulang. (7) Menggunakan system, Perangkat lunak yang sudah diuji dan disetujui oleh pelanggan siap digunakan.

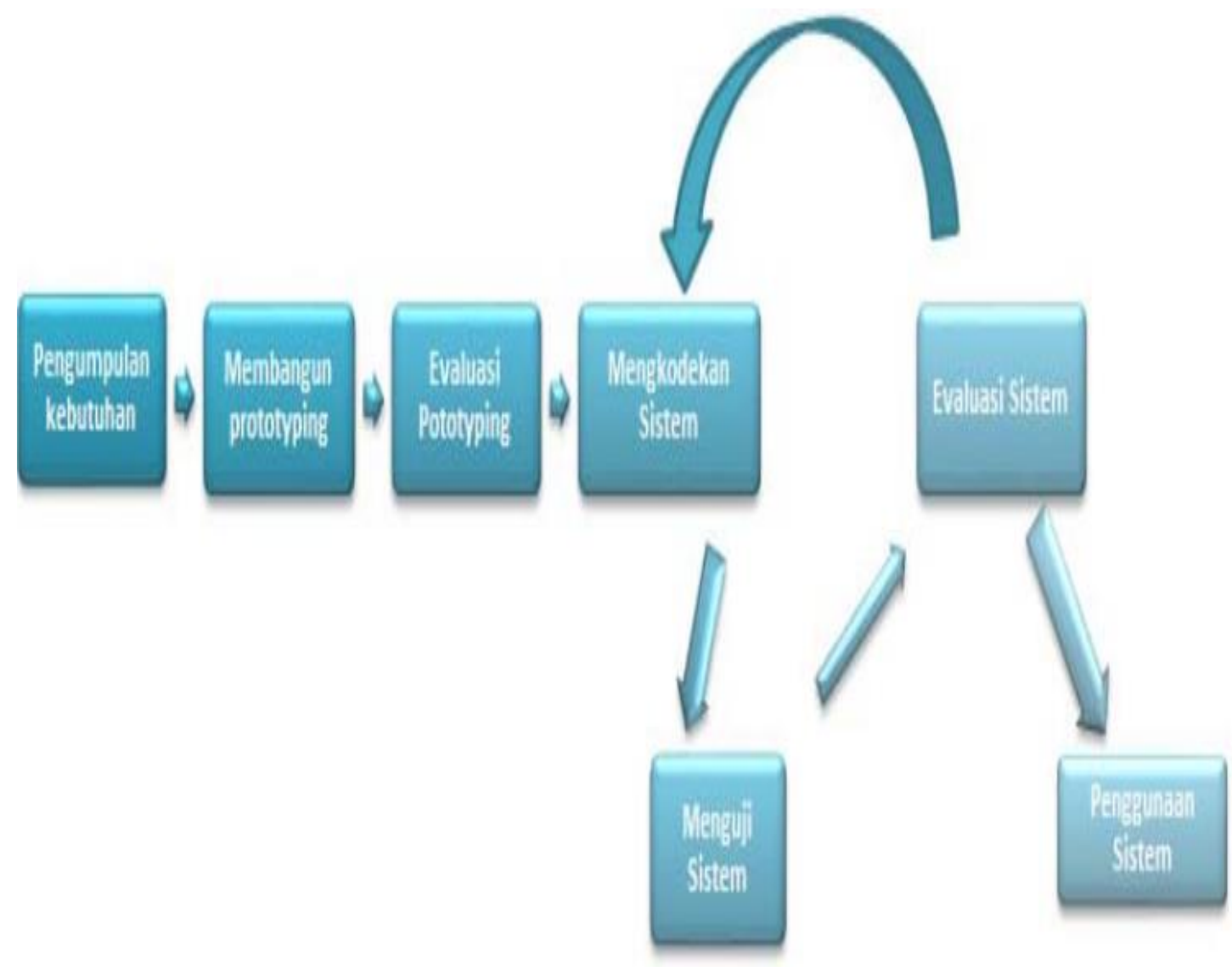

Sumber: (Sahfitri, 2019)

Gambar 1. Ilustrasi Model Prototype

\section{Hasil dan Pembahasan}

Untuk perancangan mesin presensi berbasis e-mail di SMP Assyairiyah Attahiriyah ini menggunakan Use Case Diagram usulan sebagai berikut: 


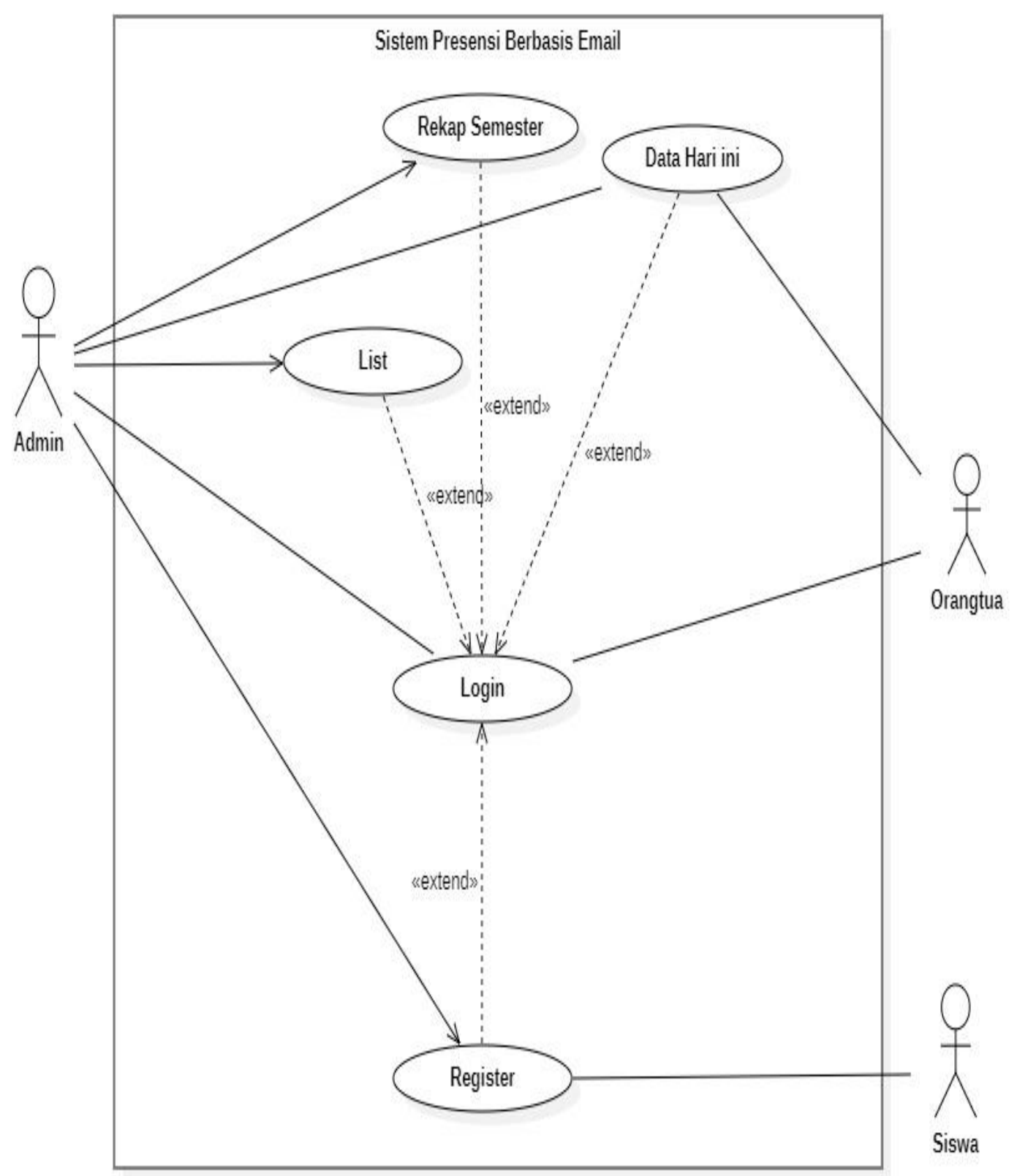

Sumber: Hasil Penelitian (2020)

Gambar 2 Use Case Diagram Prototype Mesin Presensi Berbasis E-mail

Pada gambar 2, ada beberapa ctor dengan masing-masing kegiatan yang dapat dilakukannya. Untuk mendaftarkan user sebagai Member terlebih dahulu admin akan mengisi data di form Register kemudian user akan melakukan Enroll jari agar terdaftar di database. Kemudian admin dapat mengelola data siswa dengan output akhir sebuah laporan kehadiran siswa.

Berikut kebutuhan sistem masing-masing ctor diatas mempunyai kebutuhan sistem yang dapat dilihat pada tabel berikut ini: 
Tabel 1. Deskripsi Use Case

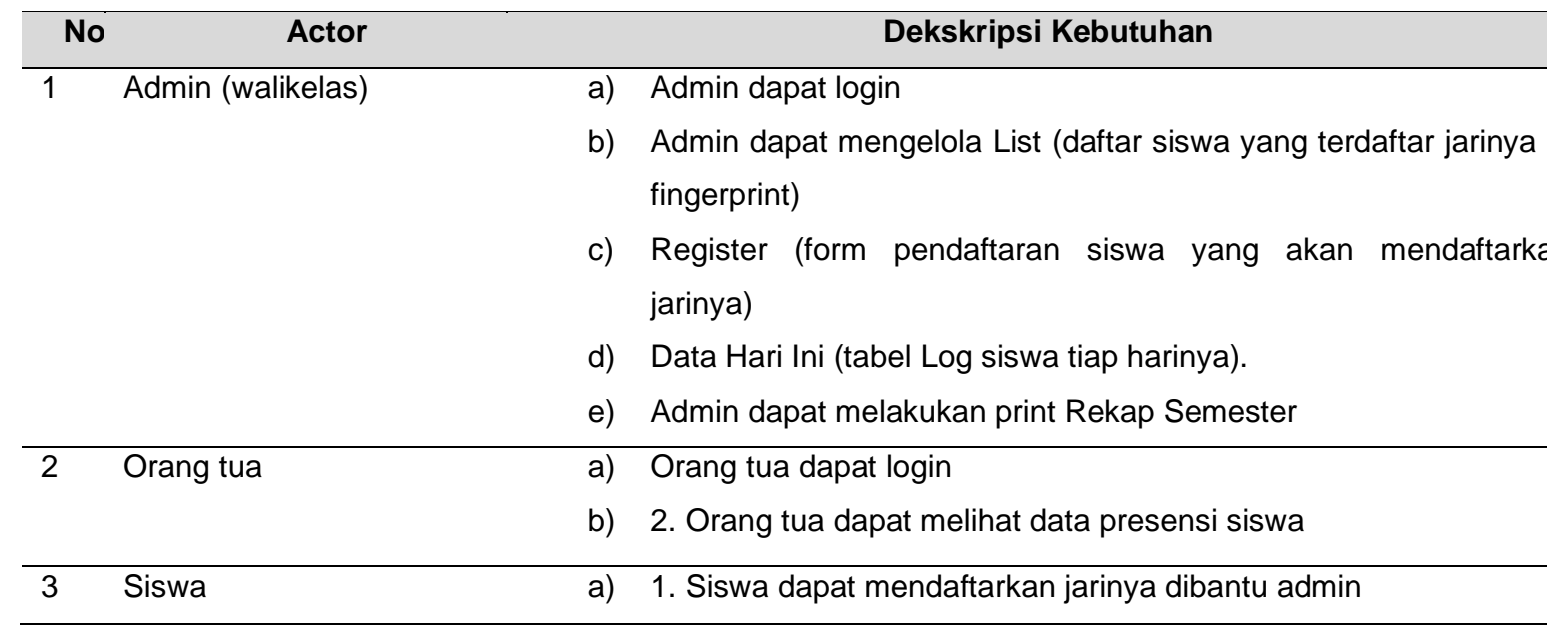

Sumber: Hasil Penelitian (2020)

Activity Diagram menggambarkan alur kerja berdasarkan aktifitas sistem. Dalam penelitian ini akan menjelaskan aktifitas sistem di dalam prototype mesin presensi berbasis email ini. Pada Gambar 3 menggambarkan activity diagram login admin

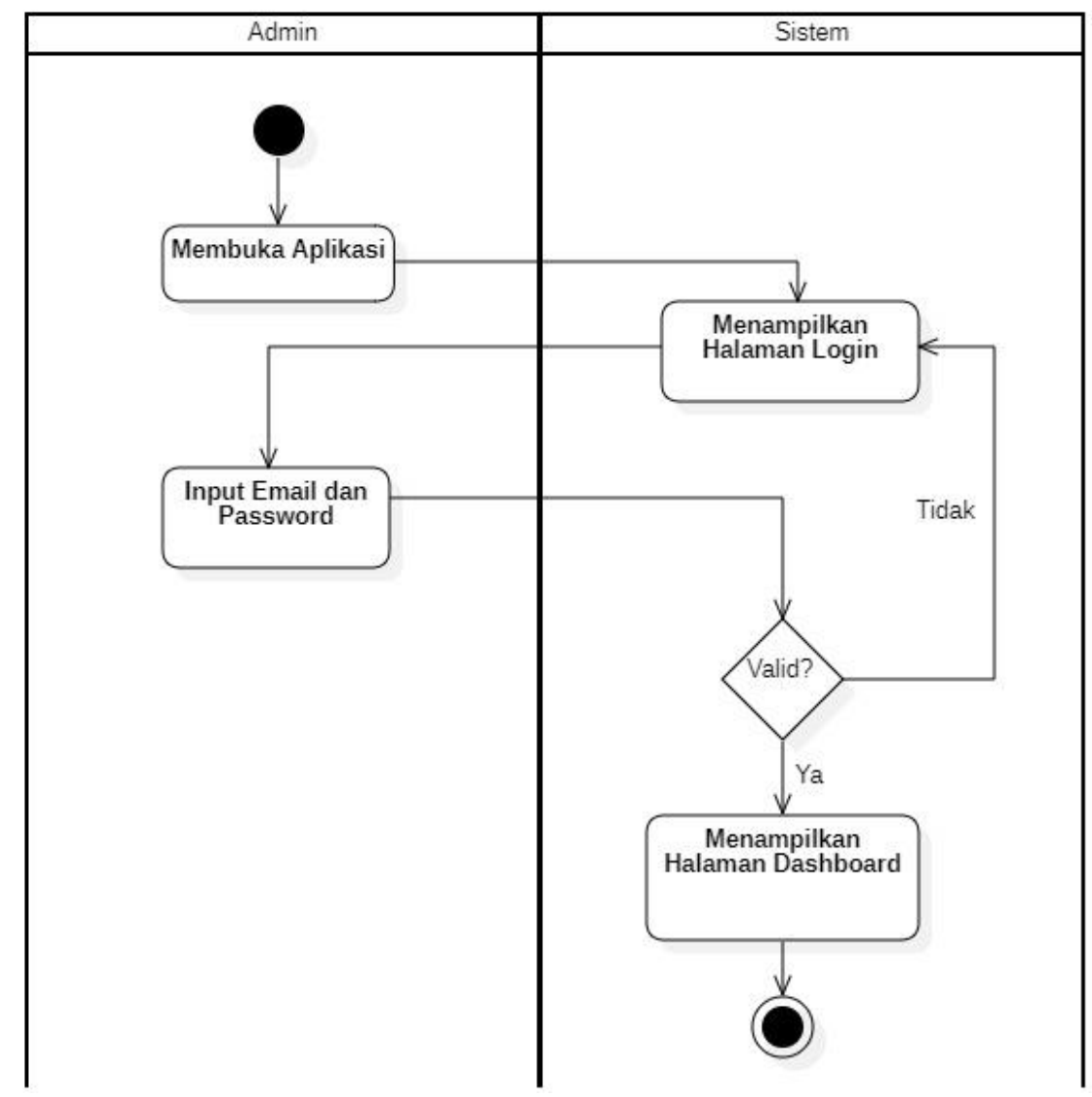

Sumber: Hasil Penelitian (2020)

Gambar 3. Activity Diagram Login Admin 
Pada gambar 3, admin dapat membuka web dan menampilkan menu halaman utama web dengan memasukan username dan password.

Prototype Mesin presensi berbasis e-mail ini menggunakan web sebagai jalannya sistem informasi dan alat berupa prototype mesin presensi sebagai media input data. Dalam web ini akan menampilkan manajemen data yang dikelola oleh seorang admin (walikelas) untuk selanjutnya melakukan penginputan data. Sedangkan hasil keluaran dari sistem ini adalah berupa laporan kehadiran siswa yang bisa dijadikan sebagai lampiran rapot siswa persemester. Siswa, walikelas, dan orang tua murid dapat melihat seluruh informasi akademik sekolah sesuai dengan batasan masing-masing.

Perancangan ini menjelaskan mengenai alat dan bahan serta bagaimana perakitannya. Alat meliputi laptop dan koneksi internet. Bahan yang dibutuhkan meliputi: NodeMCU, buzzer, sensor fingerprint, LCD 12x6 dengan modul I2C, Kabel Jumper.

Berikut prototype rancangan rangkaian dari alat yang diusulkan, dapat dilihat dari Gambar 4 yang menggambarkan rangkaian komponen Alat dan Bahan.
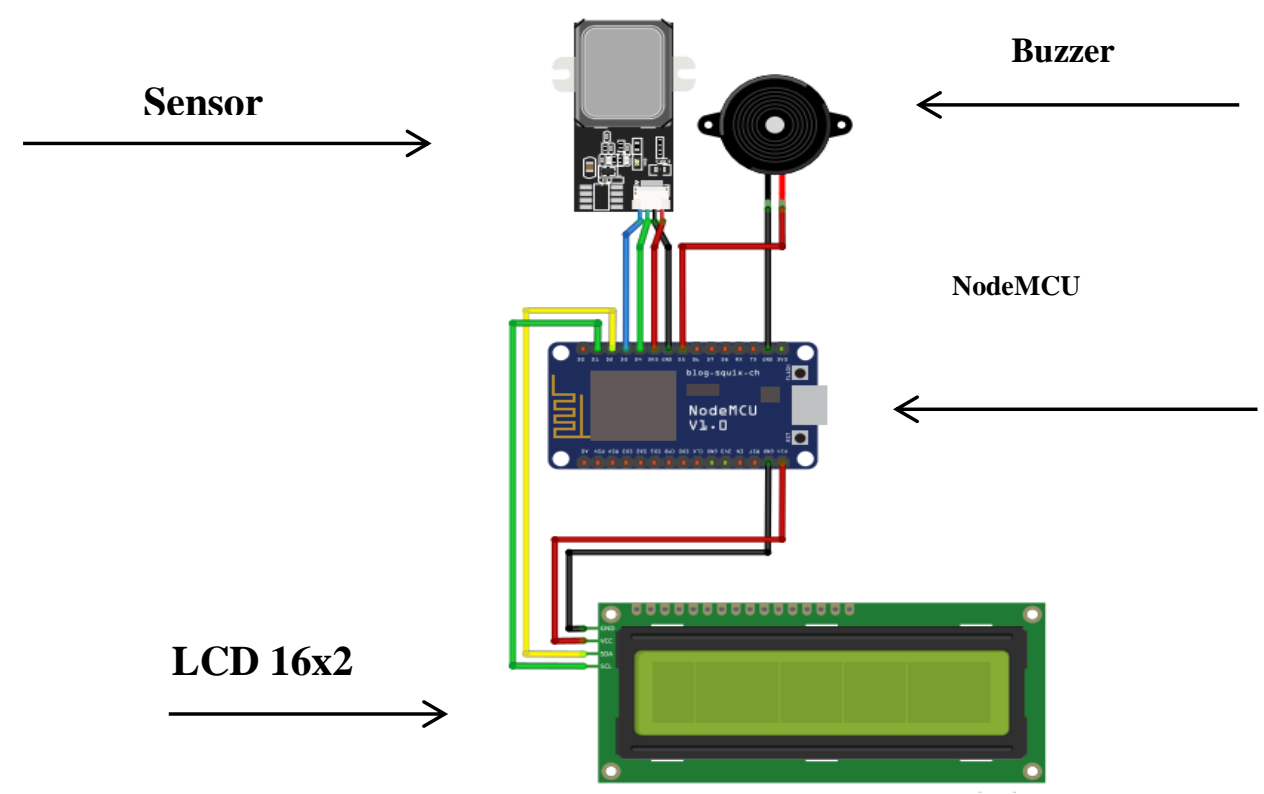

Sumber: Hasil Penelitian (2020)

Gambar 4. Rangkaian Komponen Alat dan Bahan

Pada Tabel 1 dijelaskan Rangkaian Komponen, dimulai dari nama komponen, Pin dam 3 komponen Pn Tujuan.

Tabel 1. Tabel Rangakaian Komponen

\begin{tabular}{lll}
\hline Nama Komponen & Pin & Komponen Pin Tujuan \\
\hline NodeMCU & Vin & VCC LCD \\
\hline GND & GND LCD \\
\hline D1 & SCL LCD \\
\hline D2 & SDA LCD \\
\hline D3 & TX Fingerprint \\
\hline
\end{tabular}




\begin{tabular}{lll}
\hline Nama Komponen & Pin & Komponen Pin Tujuan \\
\hline D4 & RX Fingerprint \\
\hline 3v3 & 3v3 Fingerprint \\
\hline GND & GND Fingerprint \\
\hline D5 & VCC Buzzer \\
\hline GND & GND Buzzer
\end{tabular}

Sumber: Hasil Penelitian (2020)

Pada proses ini penulis melakukan coding pada aplikasi arduino, langkah- langkahnya adalah sebagai berikut 1) Buka aplikasi Arduino, 2) Hubungkan alat dengan laptop menggunakan kabel usb, pastikan alat terbaca pada aplikasi arduino yaitu dengan memastikan board dan prot sudah sesuai, 3) Lakukan penulisan koding dan upload koding dengan klik upload pada aplikasi Arduino, 4) Tunggu hingga proses selesai.

Setelah sistem sudah menjadi suatu perangkat lunak yang siap pakai, maka di tes terlebih dahulu sebelum digunakan. Berikut tabel uji coba dari alat.

Tabel 2. Tabel Uji Coba

\begin{tabular}{lll}
\hline Nama Siswa & Respon Sensor Fingerprint & Keterangan \\
\hline Nama Siswa 1 & Tidak Cocok & Jari Tidak Terdaftar \\
\hline Nama Siswa 2 & Cocok & Hadir \\
\hline Nama Siswa 3 & - & Alfa
\end{tabular}

Sumber: Hasil Penelitian (2020)

Gambar 5 adalah tampilan ketika alat siap menerima sidik jari siswa dan jari bisa di letakan di sensor fingerprint.

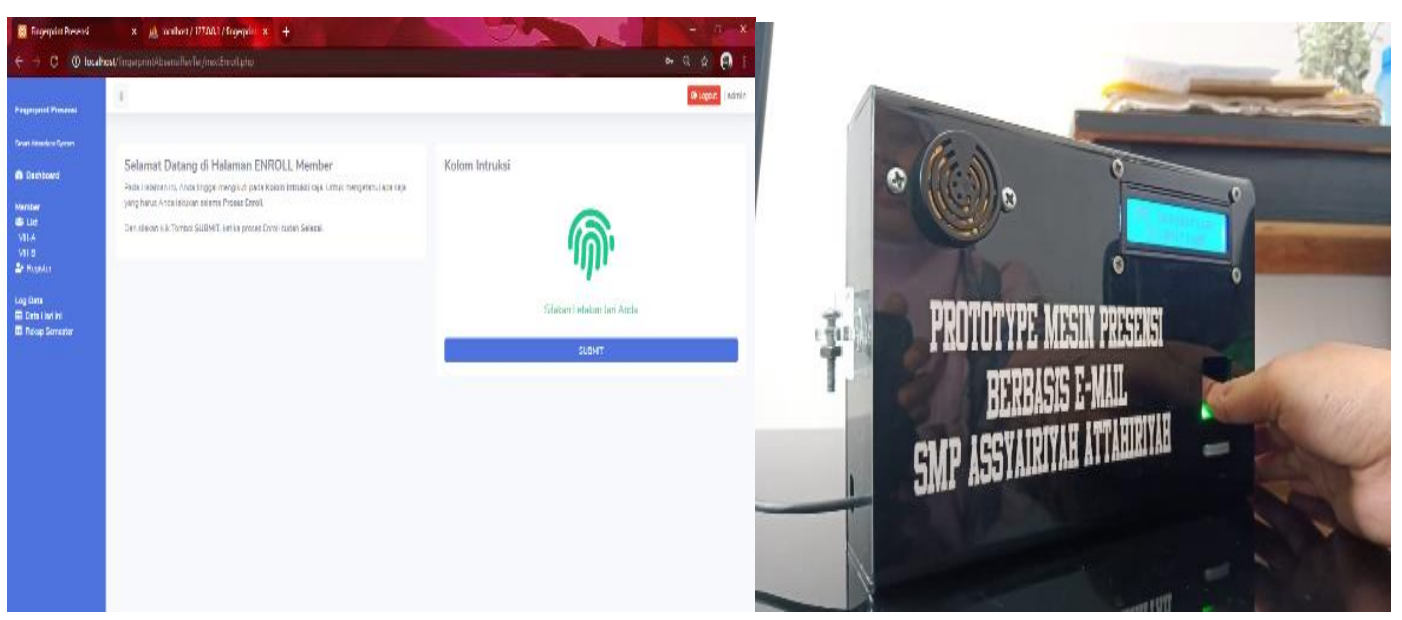

Sumber: Hasil Penelitian (2020)

Gambar 5. Tampilan Enroll Sudah Siap dan Tampilan Tap Fingerprint 


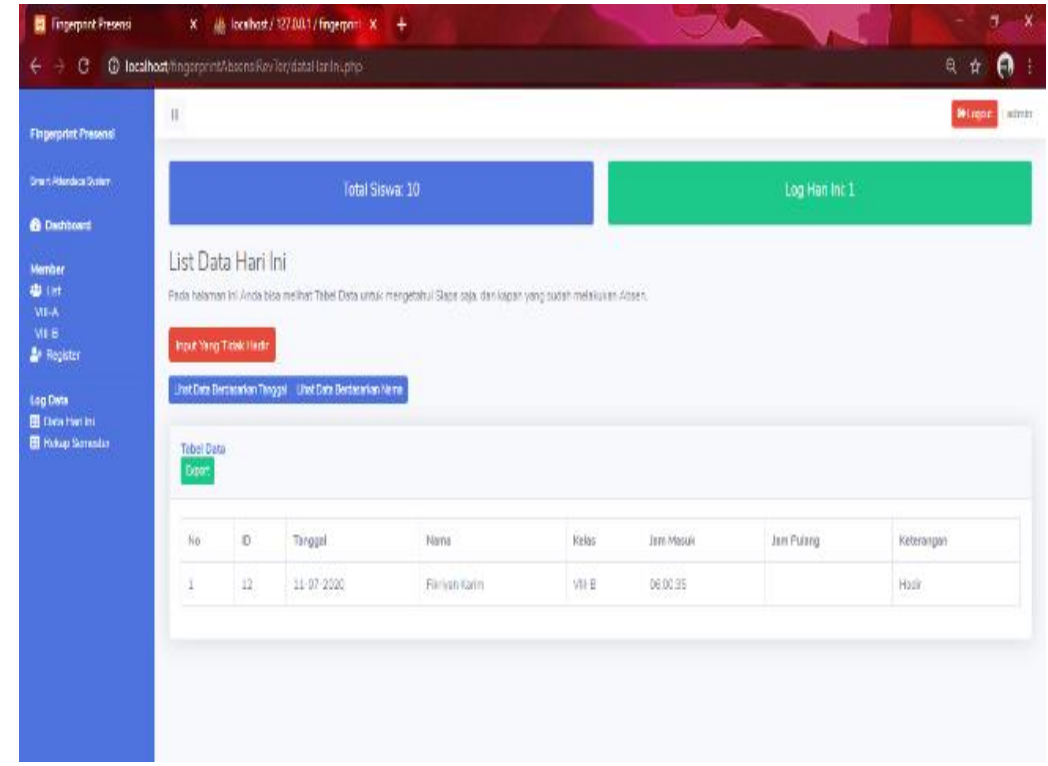

Sumber: Hasil Penelitian (2020)

Gambar 6. Tampilan di Web Saat Siswa Masuk

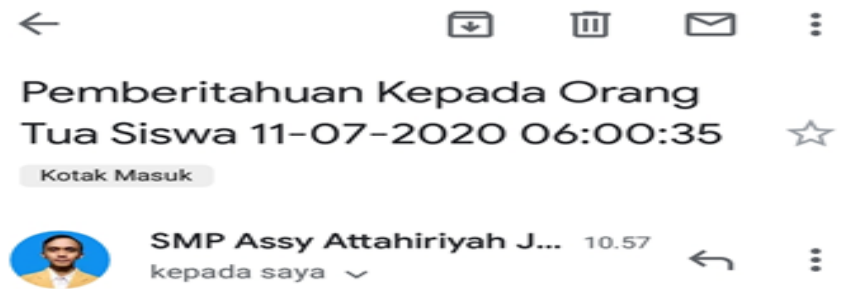

Selamat Pagi,Bapak/lbu Wali Murid, diinformasikan bahwa anak anda yang bernama Fikriyah Karim telah tiba disekolah pada 11-07
2020 Jam $0600: 35$ Terimakasih.

Sumber: Hasil Penelitian (2020)

Gambar 7. Tampilan E-mail Saat Masuk Sekolah

Pada web data akan masuk setelah siswa melakukan tap pada fingerprint, informasi yang terdapat pada web adalah No, ID, Tanggal, Nama, Kelas, Jam Masuk, Jam Pulang dan 
Keterangan. E-mail akan dikirim oleh web jika data masuk ke database dan orang tua akan menerima e-mail tersebut.

Pengujian Prototype Mesin Presensi Berbasis E-mail ini menggunakan pengujian black box testing yaitu pengujian yang dilakukan untuk menguji sistem dan user interface oleh pengguna apakah sistem yang dibuat dapat berfungsi dengan baik dan sesuai dengan apa yang diharapkan.

Tabel 3. Pengujian Black Box

\begin{tabular}{|c|c|c|c|c|}
\hline No & Deskripsi Pengujian & Skenario & Hasil Yang Diharapkan & $\begin{array}{l}\text { Hasil } \\
\text { Pengujian }\end{array}$ \\
\hline 1 & Login & $\begin{array}{l}\text { Admin dan user melakukan login } \\
\text { dengan nout username dan } \\
\text { password }\end{array}$ & $\begin{array}{l}\text { Admin dan user dapat } \\
\text { masuk kedalam sistem } \\
\text { sesuai dengan tampilan } \\
\text { login. }\end{array}$ & Berhasil \\
\hline 2 & List & Admin Masuk kedalam kelas & $\begin{array}{lr}\text { Admin dapat } & \text { masuk } \\
\text { kedalam menu } & \text { kelas } \\
\text { dan } & \text { sistem } \\
\text { menampilkan menu } \\
\text { kelas yang berisi } \\
\text { siswa. }\end{array}$ & Berhasil \\
\hline 3 & Register & $\begin{array}{l}\text { Admin melakukan pengisian form } \\
\text { dan mendaftarkan jari siswa pada } \\
\text { alat fingerprint. }\end{array}$ & $\begin{array}{lr}\text { Admin } & \text { dapat } \\
\text { menambahkan data } \\
\text { siswa, dan fingerprint } \\
\text { dapat membaca sidik } \\
\text { jari siswa }\end{array}$ & Berhasil \\
\hline 4 & Log Data hari Ini & $\begin{array}{l}\text { Admin memilih menu Log data hari } \\
\text { ini dan memilih apakah dilihat } \\
\text { berdasarkan tanggal atau nama. } \\
\text { Admin mengedit pula siswa yang } \\
\text { alfa. }\end{array}$ & $\begin{array}{l}\text { Admin dapat masuk dan } \\
\text { sistem menampilkan } \\
\text { informasi data kehadiran } \\
\text { siswa. Admin dapat } \\
\text { mengubah alfa siswa } \\
\text { menjadi izin atau sakit. }\end{array}$ & Berhasil \\
\hline 5 & Rekap Semester & $\begin{array}{l}\text { Admin Memilih menu rekap } \\
\text { semester, kemudian klik print sesuai } \\
\text { dengan nama anak yang akan } \\
\text { direkap datanya. }\end{array}$ & $\begin{array}{l}\text { Admin dapat masuk dan } \\
\text { melakukan print data } \\
\text { kehadiran siswa }\end{array}$ & Berhasil \\
\hline 6. & Tampilan Login User & $\begin{array}{l}\text { User memasukan email dan } \\
\text { password user. }\end{array}$ & $\begin{array}{l}\text { user dapat masuk } \quad \text { l } \\
\text { halaman user }\end{array}$ & Berhasil \\
\hline 7. & Tampilan Utama User & $\begin{array}{l}\text { User memasukan e-mail dan } \\
\text { password }\end{array}$ & $\begin{array}{l}\text { menampilkan menu utan } \\
\text { user }\end{array}$ & Berhasil \\
\hline
\end{tabular}

\section{Kesimpulan}

Kesimpulan dari penelitian ini 1) Dengan adanya sistem ini tingkat disiplin siswa untuk hadir disekolah akan meningkat, sehingga menurunkan tingkat absensi siswa, 2) dengan adanya sistem ini diharapkan dapat mempermudah pihak sekolah dalam mengelola data 
presensi siswa, sehingga mengurangi potensi kerusakan hingga kehilangan data presensi siswa, 3) Dalam implementasinya orang tua dan pihak sekolah dapat memonitoring kehadiran siswa kapan pun dan dimanapun, 4) Sistem ini membantu orang tua mendapatkan informasi masuk maupun kepulangan siswa dari sekolah, 5) Sistem ini memberikan data yang lebih akurat dan rapi.

\section{Daftar Pustaka}

Aji, K. P., Darusalam, U., \& Nathasia, N. D. (2020). Perancangan Sistem Presensi Untuk Pegawai Dengan RFID Berbasis lot Menggunakan Nodemcu ESP8266. JOINTECS (Journal Of Information Technology And Computer Science), 5(1), 25-32. Https://Doi.Org/10.31328/Jointecs.V5i1.1222

Andalia, F., \& Setiawan, E. B. (2015). Pengembangan Sistem Informasi Pengolahan Data Pencari Kerja Pada Dinas Sosial Dan Tenaga Kerja Kota Padang. Jurnal Ilmiah Komputer $\begin{array}{llll}\text { Dan Informatika } & \text { (KOMPUTA), 93-98. }\end{array}$ Https://Ojs.Unikom.Ac.Id/Index.Php/Komputa/Article/View/2431

Andita, R., Paramidita, N., Rachmatullah, P., Akbar, S., Permata, S., \& Mulyaningsih, S. (2016). Analisis Dan Perancangan Sistem Informasi Pelayanan Obat Di Apotek Generik. Jurnal Edukasi Dan Penelitian Informatika (JEPIN), 2(1), 21-26. Https://Jurnal.Untan.Ac.Id/Index.Php/Jepin/Article/View/15463/13621

Efrianto, R., \& Fahruzi, I. (2016). Sistem Pengaman Motor Menggunakan Smartcard Politeknik Negeri Batam. Integrasi, 8(1), 1-5. Https://Core.Ac.Uk/Download/Pdf/229847585.Pdf

Faizal, M., \& Putri, S. L. (2017). Sistem Informasi Pengolahan Data Pegawai Berbasis Web (Studi Kasus Di Pt Perkebunan Nusantara VIII Tambaksari). Jurnal Teknologi Informasi Dan Komunikasi, $1-15$.

Https://Jurnalstmiksubang.Ac.Id/Index.Php/Jtik/Article/View/114/Pdf

Habibullah, Pulungan, A. B., \& Pratama, E. (2018). Monitoring Kehadiran Siswa Menggunakan SMS Gateway Berbasis Arduino. Prosiding Seminar Nasional Teknik Elektro FORTEl, 277-281. Http://Repository.Unp.Ac.Id/21820/1/E-P033_FORTEI-277-281 12.Pdf

Hendini, A. (2016). Pemodelan Uml Sistem Informasi Monitoring Penjualan Dan Stok Barang (Studi Kasus: Distro Zhezha Pontianak). Jurnal Khatulistiwa Informatika, 4(2), 107-116. Https://Doi.Org/10.2135/Cropsci1983.0011183x002300020002x

Ismaredah, E. (2015). Keamanan E-Mail Menggunakan Metode Enkripsi Gnupg Dengan $\begin{array}{llll}\text { Squirellmail Dan } \quad \text { Thunderbird. Jupiter, } & \text { 7(2), }\end{array}$

Https://Media.Neliti.Com/Media/Publications/289148-Keamanan-E-Mail-MenggunakanMetode-Enkri-2fb119a3.Pdf

Kurnia, D., \& Widiasih, V. (2019). Implementasi Nodemcu Dalam Prototipe Sistem Pemberian Pakan Ayam Otomatis Dan Presisi Berbasis Web. Jurnal Teknologi, 11(2), 169-177. Https://Jurnal.Umj.Ac.Id/Index.Php/Jurtek/Article/View/2838/3288

Kuswara, H., \& Kusmana, D. (2017). Sistem Informasi Absensi Siswa Berbasis Web Dengan 
SMS Gateway Pada Sekolah Menengah Kejuruan Al - Munir Bekasi. Indonesian Journal On Networking And Security (ljns), 6(2), 17-22. Http://ljns.Org/Journal/Index.Php/ljns/Article/View/22/22

Martono, M. (2020). Perancangn Prototype Aplikasi Pengelolaan Inventaris Barang. Jurnal IImiah Media Sisfo, 12(2), 38. Https://Doi.Org/10.33998/Mediasisfo.2019.13.1.566

Maulana, S., Riyanto, J., \& Wicaksono, M. F. (2019). Design Of Student Attendance Information System With Fingerprints. Prosiding Seminar Nasional Informatika Dan Sistem Informasi, 662(2), 156-166. Https://Doi.Org/10.1088/1757-899X/662/2/022039

Sahfitri, V. (2019). Prototype E-Katalog Dan Peminjaman Buku Perpustakaan Berbasis Mobile. Jurnal Sisfokom (Sistem Informasi Dan Komputer), 8(2), 165. Https://Doi.Org/10.32736/Sisfokom.V8i2.665

Wiryadinata, R., Istiyah, U., Fahrizal, R., Priswanto, P., \& Wardoyo, S. (2017). Sistem Presensi Menggunakan Algoritme Eigenface Dengan Deteksi Aksesoris Dan Ekspresi Wajah. Jurnal Nasional Teknik Elektro Dan Teknologi Informasi (JNTETI), 6(2), 222-229. Https://Doi.Org/10.22146/Jnteti.V6i2.319

Wulanningrum, R., \& Pamungkas, D. P. (2018). Sistem Pengenalan Wajah Untuk Presensi Kuliah Dengan Metode Eigenface Pca (Principal Component Analysis) Dan City Block. Simki-Techsain, 02(03), $1-10$. Http://Simki.Unpkediri.Ac.Id/Mahasiswa/File_Artikel/2018/Cbfcafc1620c0af4778056f10e2e f551.Pdf 